\title{
Peningkatan Hasil Belajar IPA Melalui Model Pembelajaran Kooperatif Tipe Tebak Kata
}

\author{
Suryadi \\ Pendidikan Anak Usia Dini, IAIN Metro \\ Jalan Ki Hajar Dewantara 15A Kampus Kota Metro, Lampung 34112 \\ E-mail: suryadi@metrouniv.ac.id
}

\begin{abstract}
Article Info
Received December 2018

Accepted Februari 2019

Published April 2019

Keywords:

Science Learning

Outcomes, Guess Word

Learning Models, Action

Research

Abstract

The purpose of this research was to describe the implementation process play letter and word and to understand improving early reading ability of children in group B1 through play letter and word. The study was conducted on group $B$ Kindergarten with of fiften children. This study used action research methods by Kemmis and Taggart which consist of 4 stages (plan, action, observation and reflection). This study consisted of two cycles, each cycles consisting of 8 sessions. Data collecting techniques used observation, field notes and documentation. Data analysis using quantitative and qualitative data. Quantitative data analysis with descriptive statistics that compare the result obtained from the first cycle and the second cycle. Analysis of qualitative data by analizing data from the observation, fields notes and documentation during the study to the steps of data reduction, data display and data verification. The result of this study showed that there was the improving early reading ability through play letter and word using learning style visual, auditory and kinesthetic with score in pre cycle 34,8 had improvement to 51,4 and become 63,5 in cycle II and excellent growing category.
\end{abstract}

\begin{abstract}
Abstrak : Tujuan dari penelitian ini adalah mendeskripsikan proses penerapan permainan huruf dan kata dan untuk mengetahui peningkatan kemampuan membaca permulaan anak kelompok B1 melalui permainan huruf dan kata. Penelitian ini dilakukan pada anak kelompok B1 yang berjumlah 15 orang. Penelitian ini adalah penelitian tindakan dengan metode Kemmis dan Taggart yang terdiri dari 4 tahap yaitu (rencana, tindakan, observasi dan refleksi). Penelitian ini terdiri dari 2 siklus masing-masing siklus sebanyak 8 pertemuan. Teknik pengumpulan data menggunakan observasi, catatan lapangan, dan dokumentasi. Analisis data menggunakan kuantitatif dan kualitatif. Analisis data kuantitatif dilakukan dengan deskripsi statistik untuk membandingkan pra siklus sampai siklus II. Analisis kualitatif dilakukan dengan menganalisis data dari observasi, catatan lapangan dan dokumentasi yang telah diverifikasi. Hasil penelitian menunjukkan terdapat peningkatan kemampuan membaca permulaan melalui permainan huruf dan kata dengan menggunakan gaya belajar visual, auditori, kinestetik (VAK) dengan skor pada pra siklus 34,8 meningkat menjadi 51,5 pada siklus I dan mengalami peningkatan sebesar 63,57 pada siklus II dengan kategori berkembang sangat baik.
\end{abstract}

Kata Kunci : Hasil belajar IPA, model pembelajaran tebak kata, penelitian tindakan 


\section{PENDAHULUAN}

Pendidikan adalah proses untuk membentuk manusia dalam mengembangkan dirinya sehingga mampu menghadapi setiap perubahan yang terjadi sejalan dengan perkembanganya. Pendidikan yang mendapat peran penting adalah pendidikan yang diperoleh pada pendidikan disekolah dasar (SD).

Berdasarkan UU Nomor 2003 pendidikan nasional adalah untuk meningkatkan kualitas Indonesia yang beriman, bertaqwa kepada tuhan yang maha Esa, berbudi pekerti luhur, berkepribadian mandiri, maju, tangguh, cerdas, kretif, terampil, berdisiplin, beretos kerja, sehat jasmani dan rohani. Sehingga sistem pendidikan nasional harus mampu menjamin pemerataan kesempatan pendidikan, peningkatan kualitas pendidikan serta relevansi dan efesiensi menejemen pendidikan untuk mengadapi tantangan sesuai dengan tuntutan prilaku kehidupan lokal, nasional, global sehingga diperlukan pembaharuan pendidikan secara terencana, terarah dan berkeseinambungan. Untuk mewujudkan sistem pedidikan yang demikian perlu adanya peran aktif dari semua pihak diantaranya adalah pemerintah, orang tua siswa dan lain-lain.

Usia 9-10 tahun merupakan siswa berada pada tahap masa operasi konkret dimana mereka sudah mulai berpikir konkret yang berkaitan dengan dunia nyata. Anak sudah berpikir secara nyata yang bisa diterima masuk akal yang tadinya berpikir dengan khayalan kemudian sudah mulai berkembang dengan cara berpikir yang nyata. Proses pengembangannya mencakup kognitif, emosional, agama yang ada pada diri siswa melalui proses pembelajaran untuk mencapai tujuan tertentu.

Sains yang dapat didefinisikan sebagai ilmu pengetahuan tentang alam yang dalam bahasa Indonesia disebut dengan ilmu pengetahuan alam yaitu ilmu pengetahuan alam sebagai produk, proses dan sikap. IPA merupakan salah satu pelajaran yang wajib dipelajari di sekolah dasar, dengan IPA anak akan dapat mempelajari diri sendiri dan alam sekitar. IPA juga merupakan mencari tahu tentang alam secara sitematis sehingga IPA bukan hanya pengumpulan 
pengetahuan yang berupa fakta-fakta, kosep-konsep, dan prinsip prinsip saja tetapi merupakan peroses penemuan juga.

Pendidikan IPA juga diharapkan menjadi wahana bagi peserta didik untuk dapat mempelajari diri sendiri dan alam sekitar. Serta pengembangan diri dalam menarapkan kedalam kehidupan sehari hari. Proses pembelajaran menerapkan pengalaman langsung untuk mengembangkan kemampuan agar memahami alam sekitar secara ilmiah.

Pembelajaran IPA khususnya materi tentang ciri-ciri dan kebutuhan mahluk hidup menjadi pembelajaran yang menarik bagi siswa dan apabila guru dapat membelajarkan secara tepat. namun ketika penelitian mengobservasi dikelas III B di SDN 05 Kebalen Bekasi Utara, pembelajaran masih bersifat konvesional yaitu pembelajaran masih berpusat kepada guru. misalnya karena proses mengajar guru masih hanya menggunakan metode ceramah, sehingga nilai IPA kelas III Masih rendah.

Dan proses pembelajaran yang diterapkan guru selama ini masih kurang mampu mengembangkan kemampuan berpikir peserta didik. Pelaksanaanya proses belajar yang berlangsung dikelas hanya diarahkan kepada kemapuan siswa untuk menghafal informasinya saja, siswa dipaksa untuk mengingat berbagai informasi yang diberikan oleh guru tanpa di tuntut untuk memahami infomasi yang diperoleh untuk menghubungkan dengan situasi dalam kehidupan seharihari. Dan masih bawah kkm ,banyak siswa yang nilai 65 presetasinya menurun dibawah kkm sedangkan kkm yang ditetapkan di SDN 05 Kebalen Bekasi Utara kkmnya 73 untuk mata Pelajaran IPA.

Bukan hanya itu saja siswa juga masih belum bisa berkonsentrasi selama pembelajaran berlangsung karena guru tidak menggunakan alat media pembelajaran yang kurang memadai selama pembelajaran berlangsung yang membuat konsentrasi siswa dalam belajar masih berkurang, siswa juga banyak yang mengeluh karena pembelajaran yang masih menggunakan model yang terpaku hanya mendengarkan guru saja sehingga siswa tidak mendapat kesempatan untuk lebih leluasa dalam belajar sehingga minat siswa rendah.

Kurangnya kerja sama antar siswa, baik dalam proses pembelajaran maupun dalam menyelesaikan setiap tugas yang diberikan oleh guru, sehingga 
nilai tertinggi IPA tersebut hanya dimiliki oleh siswa yang aktif dalam mengikuti pembelajaran IPA. Dalam pembelajaran ini kususnya pada pelajaran IPA pada saat menjawab soal siswa banyak yang belum mengerti dan masih sangat kurang ini disebabkan karena siswa kurang teliti untuk memahami menjawab dan meneyselesaikan soal yang diberikan oleh guru.

Agar pembelajaran IPA menjadi pembelajaran yang aktif dan menyenangkan,salah satu penerapan dengan mengunakan model tebak kata. "Berdasarkan hasil penelitian dapat dimaknai bahwa penerapan pembelajaran model tebak kata diduga mampu meningkatkan hasil belajar siswa. Untuk membuktiknnya, maka dilakukannya oenelitian tindakan kelas (PTK) dengan judul penerapan model pembelajaran tebak kata untuk menigkatkan hasil belajar IPA aiaswa kelas V semester ganjil di SD 1 Depeha kecematan kubutambahan kabupaten buleleng tahun pelajaran 2016/2017 (Ryantika \& dkk, 2016).

Berdasarkan hasil penelitian secara umum dapat disimpulkan, bahwa terdapat pengaruh model pembelajaran cooperative tipe tebak kata terhadap hasil belajar siswa kelas V. Hasil angket respon siswa pada Gambar 1 menunjukkan siswa memberikan respon positif terhadap model pembelajaran kooperatif tebak kata dengan jumlah $99 \%$ dan hanya $1 \%$ yang memberikan respon negatif dan berdasarkan interprestasi respon siswa dalam Riduwan bahwa kriteria respon siswa $\geq 81 \%$-100\% merupakan respon yang sangat baik, dengan demikian siswa memberikan respon positif sangat baik terhadap pembelajaran kooperatif tebak kata (Syamsiyah, \& Wedyawati, 2017).

Dengan demikian pembelajaran tebak kata ini murni berorientasi pada aktivitas individu siswa yang dilakukan dalam bentuk permainan. Maka perlu adanya model pembelajaran yang tepat serta memotivasi dan meningkat siswa dalam mempelajari konsep pembelajaran yaitu pembelajaran IPA. Pengguna model pembelajaran yang tepat sangat berpengaruh dengan keberhasilan dari kegiatan pembelajaran. Upaya yang dilakukan untuk dapat digunakan dalam pembelajaran IPA khusus nya materi, ciri-ciri dan kebutuhan mahluk hidup pada jenjang pendidikan Sekolah Dasar adalah Model Pembelajaran Tebak Kata. 


\section{Hasil Belajar}

Hasil Belajar adalah perubahan perubahan yang terjadi pada diri siswa, baik yang menyakut aspek kognitif, afektif, dan psikomotor sebagai hasil dari kegiatan belajar. Pengertian hasil belajar diatas dipertegas oleh Nawawi dalam K.Ibrahim bahwa Hasil Belajar dapat diartikan sebagai tingkat keberhasilan siswa dalam mepelajari materi disekoah yang dinyatakan dalam skor yang diperoleh hasil tes mengenal sejumlah materi pelajaran tertentu (Susanto, 2015).

Hasil belajar adalah kemampuan yang diperoleh anak setelah melakukan kegiatan belajar. Karena belajar itu sendiri merupakan suatu proses perseorangan yang berusaha memperoleh suatu perubahan prilaku yang relatif menetap. Dalam kegiatan pembelajaran biasanya guru menetap tujuan belajar. Anak yang berhasil dalam belajar adalah berhasil mencapai tujuan, tujuan pembelajaran atau tujuan inrasional. Artinya hasil belajar dapat diartikan hasil pembelajaran dapat dikatagorikan oleh pakar pendidik sebagaimana tersebut diatas tidak dilihat secara fregmentasi saja atau terpisah melainkan komperhensif.

Winkel Mengemukakan, "bahwa Hasil Belajar adalah perubahan yang mengakibatkan manusia berubah dalam sikap dan tingkah lakunya. Aspek perubahan itu mengacu pada taksonomi tujuan pengajaran yang dikembangkan oleh bloom,simpon dan harrow mencangkup aspek kognitif, afektif dan psikomotor. hasil belajar adalah perubahan prilaku mahasiswa akibat belajar. Perubahanan perilaku disebabkan karena dia mencapai penguasaan atas sejumlah bahan yang diberikan dalam proses belajar mengajar. Pencapaian itu didasari atas tujuan pengajaran yang telah ditetapkan. hasil itu dapat berupa perubahan dalam aspek kognitif, afektif maupun psikiomotorik. (Purwanto, 2011).

Hasil belajar merupakan tingkat keberhasilan yang dicapai oleh siswa setelah mengikuti suatu kegiatan pembelajaran, dimana tingkat keberhasilannya tersebut ditandain dengan skala nilai berupa huruf atau kata ataupun simbol (Dimyati dan Mudijono, 2015).

Abdurrahman Mengatakan Bahwa Hasil Belajar adalah kemampuan yang diperoleh anak setelah melalui kegiatan belajar. Hasil Belajar adalah penilaian siswa ketika siswa sudah melakukan kegiatan belajar dari kegitan belajar untuk dapat menilai anak susuai dengan tujuan pembelajaran (Jihad, 2013). 
Hasil belajar merupakan hal yang sangat penting dalam pendidikan dan dapat dipandang sebagai salah satu ukuran keberhasilan siswa dalam pendidikan disekolah'. Hasil Belajar adalah sebagai salah asatu tolak ukur keberhasilan siswa dalam sebuah pendidikan dengan tujuan tertentu. Hasil belajar adalah sebagai salah satu tolak ukur bagi siswa ketika siswa sudah melakukan proses pembelajaran yang biasanya ditandai dengan nilai proses pembelajaran siswa tersebut apakah siswa itu sudah mencapai tujuan pembelajaran tersebut atau belum (Rahmah, dkk, 2014).

\section{Model Pembelajaran Kooperatif Tipe Tebak Kata}

Imas \& Sani mengatakan “ Tebak Kata merupakan model yang menggunakan media kartu teka teki yang berpasangan dengan kartu jawaban teka teki." Pada saat ini diperlukan siswa bukan berarti bahwa siswa tidak mampu belajar sendiri melainkan siswa diajak untuk dapat mengaktifkan diri untuk berinteraksi dengan baik. Selain itu, pada model ini siswa dapat mempunyai kekayaan bahasa, sangat menarik sehingga setiap siswa ingin mencobanya (Imas \& Sani, 2015).

Model Kooperatif Tebak Kata merupakan model pembelajaran yang berbasis permainan yang sesuai dengan karakter siswa sekolah dasar yang senang bermain dan berkompetensi. Model Pembelajaran Tebak Kata proses pelaksanaan pembelajaran permaian yang dapat menyesuaikan karakteristik siswa yang masih senang dengan bermain yang berkompetensi (Syamsiyah, \& Wedyawati, 2017). Ridwan Abdullah sani berpendapat "Model Tebak Kata dalah pembelajaran yang menggunakan media kartu kata yang berpasangan dengan kartu jawaban teka teki. Permaianan teka teki dilaksanakan dengan cara siswa menjodohkan kartu soal teka teki dengan kartu jawaban yang tepat". Model pembelajaran dengan menggunakan kartu yang dapat mempermudah anak dalam proses pembelajaran (Ferianti, \& Hamzah, 2017).

Model Pembelajaran Tebak Kata merupakan pembelajaran kooperatif yang mengembangkan keterampilan berpikir maupun keterampilan sosial siswa seperti, bekerja sama, setia kawan dan mengemukakan pendapat. Keterampilan ini sangat dibutuhkan secara kelanjutan pada keghidupan siswa. Keterampilan yang 
diperoleh siswa tidak hanya berhenti setelah pembelajaran usai melainkan pengalaman yang diperoleh selama bekerja kelompok dapat diterapkan kembali pada kelompok lainnya melalui prilaku yang positif dan akan diterapkan dalam berbagai kehidupan (Suryatman, 2017).

Model Pembelajaran Tebak Kata adalah model pembelajaran berbasis permainan dengan menggunakan kartu kata yang dapat mengembangkan keterampilan berpikir dan keterampilan sosial dan menumbuhkan rasa bekerja sesama antara kelompok sehingga menciptakan suasana pembelajaran yang aktif.

"Tujuan model pembelajaran tebak kata adalah untuk memudahkan guru dalam menyampaikan mata pelajaran dan membuat suasana menyenangkan selama proses pembelajaran berlangsung, sehingga siswa termotivasi dalam belajar serta mudah menerima pelajaran yang diberikan oleh guru (Zekrurrahman, 2013).

Suprijono Mengemukakan langkah-langkah Model Pembelajaran Tebak Kata adalah : 1) Guru menjelaskan kompetensi yang ingin dicapai atau materi kurang kurang lebih 45 menit. 2) Guru menyuruh siswa untuk berdiri berpasanga didepan kelas. 3) Seorang siswa diberi kartu berukuran 10 x $10 \mathrm{~cm}$ yang nanti dibacakan pasangannya. Seorang siswa yang lain diberi kartu ukuran 5 x $2 \mathrm{~cm}$ yang isi nya tidak boleh dibaca (dilipat) kemudian ditempelkan di dahi atau diselipkan di telinga. 4) Sementara siswa membawa kartu 10 x10 cm membacakan kata-kata yang tertulis dalamnya sementara pasangannya menebak apa yang dimaksud dalam kartu 10 × $10 \mathrm{~cm}$, jawaban tepat bila sesuai dengan isi kartu yang ditempelkan di dahi atau ditelinga.

Apabila jawabanya tepat (sesuai dengan yang tertulis dikartu), maka pasangan itu boleh duduk. bila belum tepat pada waktu yang telah ditetapkan boleh mengarahkan dengan kata-kata lain asal jangan langsung memberi jawabannya (Agus Suprijiono).

Imas \& Sani (2015) berpendapat Kelebihan Model Pembelajaran Tebak Kata sebagai berikut :

Kelebihan Model Pembelajaran Tebak Kata :

1. Anak akan mempunyai kekayaan bahasa.

2. Sangat menarik sehingga setiap siswa ingin mencobanya. 
3. Siswa menjadi tertarik untuk belajar.

4. Memudahkan dalam menanamkan konsep pelajaran dalam ingatan siswa (Imas \& Sani, 2015).

Model Pembelajaran Tebak Kata adalah model pembelajaran yang berbasis permaianan dengan menggunakan kartu kata agar siswa lebih mudah serta meningkatkan daya ingat siswa dalam menerima materi yang disampaikan oleh guru.

\section{METODE}

Jenis penelitian ini menggunakan penelitian tindakan (action research). Desain dalam penelitian ini menggunakan Kemmis dan Taggart yang meliputi 4 tahap yaitu tahap perencanaan, tindakan, pengamatan dan refleksi. Dalam model Kemmis dan Taggart tindakan dan observasi dijadikan sebagai suatu kesatuan yang tidak dapat terpisahkan. Teknik pengumpulan data yang digunakan dalam penelitian ini adalah observasi, catatan lapangan dan dokumentasi.

\section{HASIL DAN PEMBAHASAN}

Pada siklus 1 , tindakan yang diberikan dilakukan secara bertahap 4 kali pertemuan, yang dalam satu minggunya sebanyak 2 kali pertemuan yang meliputi tahap perencanaan, pelaksanaan, pengamatan, dan refleksi.

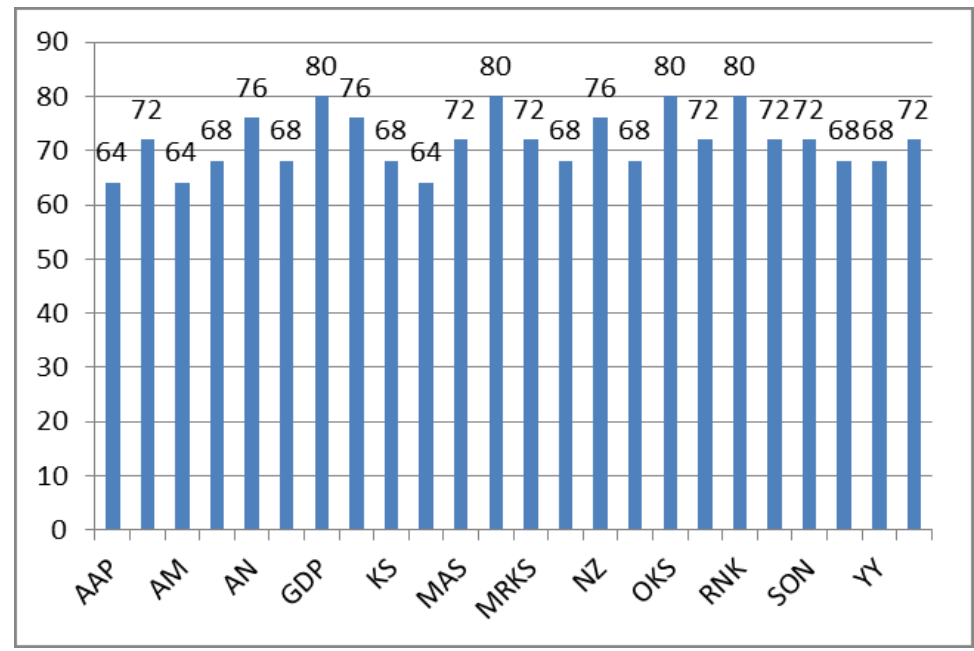


Grafik 1. Hasil Belajar setelah diberi tindakan

Berdasarkan data pada grafik diatas, hasil belajar IPA siswa setelah diberi tindakan pada siklus I rata-rata kelas adalah 71,67\% mengalami kenaikan yang cukup baik jika dibandingkan dengan rata-rata kelas prapenelitian yaitu 56,32\%. Maka didapatkan presentase kenaikan sebesar 15,35\%, tetapi belum mencapai KKM yang ditentukan yaitu $73 \%$. tes pada siklus I sebagaimana terlihat pada tabel diatas,menunjukan sebagian kecil siswa sudah menguasai materi dan mampu untuk meningkatkan hasil belajar IPA dengan baik. Pada siklus I ini, dari 24 siswa tersisah 17 siswa yang belum mencapai KKM dengan nilai terendah 64, dan 7 siswa sudah mencapai KKM dengan nilai tertinggi 80. Hal ini menjadi panduan bagi peneliti dan kolaborator untuk melaksanakan tindakan yang lebih baik pada siklus selanjutnya yaitu siklus II.

Penelitian melakukan tindakan siklus II yang meliputi tahap perencanaan, pelaksanaan, pengamatan dan refleksi.

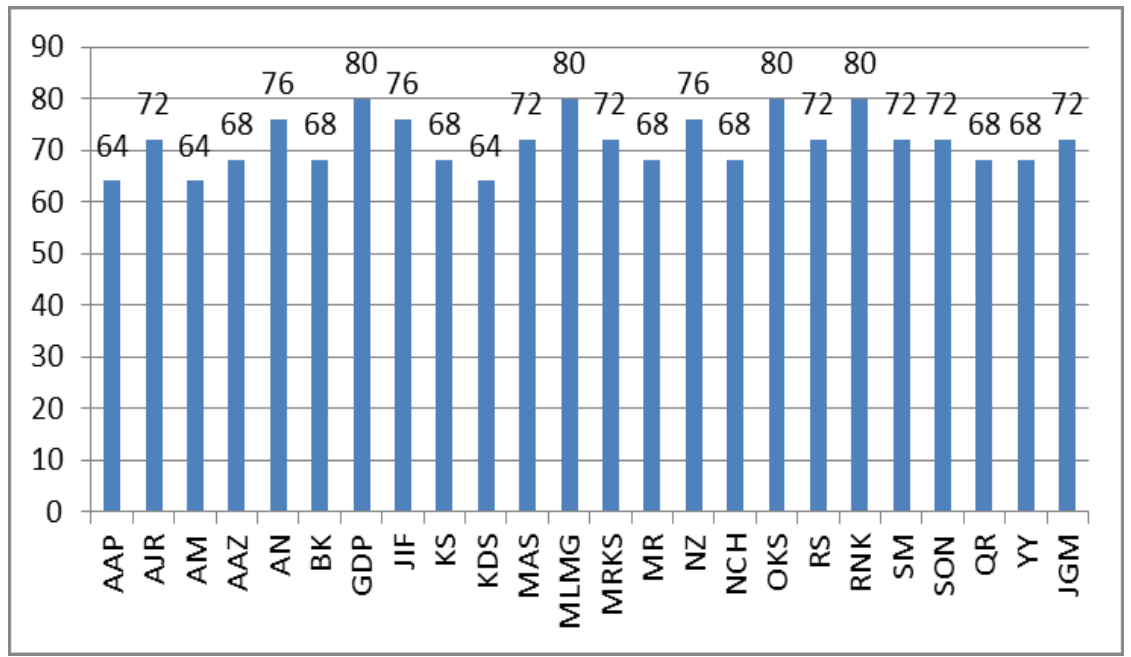

Grafik 2. Hasil Belajar IPA setelah diberi tindakan pada Siklus II

Berdasarkan dari data yang diperoleh, hasil belajar IPA setelah diberi tindakan pada siklus II, rata-ratanya adalah $87,33 \%$ mengalami peningkatan jika dibandingkan dengan rata-rata pada siklus I yaitu $71.67 \%$ berdasarkan perbandingan rata- rata siklus I dengan siklus II, maka didapat kenaikan prosentase sebesar $15.66 \%$. 
Dan hasil analisis data tes pada siklus II sebagaimana terlihat pada table diatas, menunjukan seluruh siswa sudah menguasai materi dan hasil belajar IPA sudah dilakukan dengan baik. Pada siklus II ini, hasil dengan nilai terendah yaitu 84, dan hasil nilai siswa yang sudah sesuai dengan KKM yaitu 73. Kemudian dengan siswa dengan nilai tertinggi yaitu 96. Pada siswa yang nilainya sudah mencapai KKM pada siklus I, disini peneliti tetap melakukan penlilaian terhadap siswa tersebut karena untuk mengetahui bahwa siklus tersebut tetap mengalami peningkatan atau tidak pada siklus II.

\section{Pembahasan}

Berdasarkan hasil analisis data kuantitatif siklus diatas, terdapat peningkatan dari data prapenelitian sampai pada tindakan siklus I kemudahan pada siklus akhir yaitu siklus II. Hasil belajar IPA saat tes awal prapenelitian memperoleh nilai ratarata sebesar 56,32\% mengalami peningkatan setelah diberi tindakan pada siklus I yaitu dengan rata-rata 71,67\%, dan kemudian mengalami peningkatan lagi setelah diberi tindakan pada siklus II yaitu dengan rata-rata sebesar 83,33\%. Dengan perolehan nilai rata-rata diatas KKM yaitu $73 \%$ maka penelitian ini sudah dianggap telah mencapai target yang telah ditentukan. Hal ini terlihat dari perkembangan interaksi anak ketika kegiatan Tebak Kata.

\section{KESIMPULAN}

Berdasarkan hasil penelitian dan pembahasan yang telah dilakukan, maka dapat disimpulkan bahwa model pembalajaran kooperatif learning tipe Tebak Kata dapa meningkatkan hasil belajar IPA. Melalui pembelajaran berkelompok ini siswa dapat memperoleh pendidikan dan pembekalan sebagai upaya agar mereka mampu menjadikan apa yang telah dipelajarinya sebagai bekal dalam memahami lingkungannya, serta sebagai bekal untuk dirinya untuk melanjutkan pendidikan

kejenjang yang lebih tinggi. Siswa diajak untuk lebih memperhatikan hal-hal yang sebenarnya terjadi disekitarnya agar siswa menjadi pribadi yang lebih peduli dalam menghadapi kehidupan bermasyarakat dengan cara mengidentifikasikan bagianbagian kecil dari ciri-ciri dan kebutuhan makhluk hidup yang ada pada dirinya dan sekitarnya. 
Pembelajaran berbasis kelompok tidak hanya mengajak siswa memahami suatu pelajaran secara langsung melalui pembahasan kelompok secara ilmiah. Akan tetapi siswa juga diajak untuk pembahasan kelompok secara ilmiah, akan tetapi siswa diajak untuk memulai kreativitas mengolah pertanyaan yang baik sehingga dalam aplikasi kehidupan nyata siswa menjadi pribadi yang lebih aktif dan terarah.

Hasil yang diperoleh telah memenuhi kriteria keberhasilan yang ditetapkan pada awal penelitian. Dengan demikian berdasarkan pembahasan hasil penelitian yang telah dilakukan, maka dapat disimpulkan :

1. Model pembelajaran kooperatif learning tipe Tebak Kata dapat meningkatkan hasil belajar Ilmu Pengetahuan Alam pada kelas III sdn 05 KEBALEN Bekasi Utara.

2. Terdapat hubungan antara keberhasilan antara keberhasilan pembelajaran dengan langkah-langkah operasional pembelajaran yang dirancang dalam peneliti tindakan kelas yang dilakukan oleh peneliti.

Berdasarkan hasil analisis data pada pra penelitian didapat prosentase sebesar $56,32 \%$, kemudian pada siklus I terjadi peningkatan dan memperoleh hasil prosentase sebesar $71,67 \%$, dan pada siklus II adalah 87,33\%. Dengan hasil peningkatan pada siklus II maka tindakan dihentikan dan penelitian selesai karena telah mencapai target ketercapaian $>73 \%$ sesuai dengan pencapaian yang diharapkan. Hasil penelitian ini juga dapat disimpulkan bahwa peningkatan dari pra intervensi sampai siklus I adalah 15,35\%, dan dari siklus I sampai siklus II terjadi peningkatan sebesar $15,66 \%$. Dengan demikian total keseluruhan peningkatan hasil belajar IPA terhitung dari mulai pra penelitian sampai pada siklus II adalah $31,01 \%$.

Dengan demikian, hipotensis tindakan yang menyatakan bahwa model pembeajaran kooperatif tipe Tebak Kata dapat meningkatkan hasil belajar IPA pada siswa kelas III SDN 05 KEBALEN Bekasi Utara.

\section{Saran}

Dalam melaksanakan penelitian ini, peneliti mengalami beberapa kekurangan sehingga peneliti mencoba memberikan saran singkat yang diharapkan berguna bagi peneliti selanjutnya. Maka peneliti mencoba mengemukakan saran-saran sebagai berikut: 
1. Sebaiknya lembaga sekolah lebih memperhatikan bagaimana perkembangan hasil belajar siswa-siswinya dan mengambil langkah-langkah yang tepat.

2. Sebaiknya guru dapat menggunakan model-model pembelajaran yang lebih inovatif.

3. Peneliti seharusnya dapat lebih mengembangkan aspek-aspek kemampuan yang diteliti, sehingga diperoleh hasil yang optimal.

4. Orang tua sebaiknya lebih pro aktif dalam membantu nakanya mengembangkan kemampuannya.

5. Bagi Peneliti Selanjutnya

Bagi peneliti selanjutnya, disarankan untuk mengadakan penelitian dengan melakukan kegiatan-kegiatan yang lebih bervariasi dan menarik bagi siswa.

\section{DAFTAR PUSTAKA}

Dimyati dan Mudjiono. (2015). Belajar dan Pembelajaran. Jakarta: PT Rineka Cipta.

Ferianti, F., \& Hamzah, A. (2017). Model Pembelajaran Cooperative Learning Tipe Tebak Kata Terhadap Hasil Belajar Siswa Mata Pelajaran Bahasa Arab di MIN Kemu OKU Selatan. JIP (Jurnal Ilmiah PGMI), 3(2), 134-143.

Imas, K., \& Sani, B. (2015). Ragam Pengembangan Model Pembelajaran. Kata Pena.

Jihad, Asep. (2013). Evalusi Pembelajaran. Yogyakarta: Multi Pressindo

Purwanto. (2011). Evaluasi Hasil Belajar. Yogyakarta: Pustaka Pelajar.

Rahmah, Fitri, Helma dan Hendra Syaifuddin. (2014). Penerapan Strategi The Firing line pada Pembelajaran Matematika Pada Siswa kelas XI IPS SMA Negri 1 Batipuh. Vol.3. No. 1.

Ryantika, P., Rati, N. W., \& Garminah, N. N. (2016). PENERAPAN PERMAINAN TEBAK KATA UNTUK MENINGKATKAN HASIL BELAJAR IPA. MIMBAR PGSD Undiksha, 4(3).

Suryatman, D. (2017). Penerapan Model Cooprative Learning Tipe Tebak Kata dalam Meningkatkan Keaktifan dan Hasil Belajar Siswa Pada Mata Pelajaran Ips Kelas Vii B di MTsN 1 Losari Kabupaten Cirebon. Edueksos: Jurnal Pendidikan Sosial \& Ekonomi, 6(1).

Susanto, Ahmad. (2015). Teori Belajar dan Pembelajaran di Sekolah Dasar. Jakarta: Kencana. 
Syamsiyah, N., \& Wedyawati, N. (2017). Pengaruh Model Pembelajaran Kooperatif Tebak Kata Terhadap Hasil Belajar Siswa Pada Materi Pesawat Sederhana Kelas V. VOX EDUKASI: Jurnal Ilmiah Ilmu Pendidikan, 8(1), 30-41.

Undang-Undang, R. I., UNDANG-UNDANG, M. E. N. J. A. D. I., \& INDONESIA, P. R. (2013). Nomor 12 Tahun 2003. Tentang Sistem Pendidikan Nasional.

Zekrurrahman, N. M. (2013). Meningkatkan Hasil Belajar Siswa Pada Materi Perjuangan Dalam Mempertahankan Kemerdekaan Indonesia Melalui Pembelajaran Kooperatif Model Tebak Kata Di Kelas V Sdn Sungai Miai 4 Banjarmasin. Paradigma, 8(1). Banjarmasin. Vol.8 .No.1 